How to cite: Strapazan, C., Haidu, I., Kocsis, I. (2019) Assessing Land Use/Land Cover Change and its Impact on Surface Runoff in the Southern Part of the Țibleș and Rodnei Mountains. 2019 "Air and Water - Components of the Environment" Conference Proceedings, Cluj-Napoca, Romania, p. 225-236, DOI: 10.24193/AWC2019 23.

\title{
ASSESSING LAND USE/LAND COVER CHANGE AND ITS IMPACT ON SURFACE RUNOFF IN THE SOUTHERN PART OF THE T,IBLES, AND RODNEI MOUNTAINS
}

\author{
Carina STRAPAZAN $N^{1}$, Ionel HAIDU ${ }^{1}$ Istvan KOCSIS ${ }^{1}$ \\ DOI: 10.24193/AWC2019_23
}

\begin{abstract}
There is an increasing need to assess and quantify the impact of land use/land cover changes, especially on surface runoff, due to rapid population growth. This study aims to investigate the land use/land cover (LULC) changes over time, for an intense rainfall event in Țibleș, Runc and Sălăuța watersheds, and their impacts on surface runoff for various antecedent moisture conditions (AMC). The GIS-based SCSCN method and the CORINE land cover (CLC) databases for 2000, 2006 and 2012 laid the foundation for this research. Results indicated that even small land cover changes can significantly affect runoff on the short time scale, with quantitatively different effects regarding moisture conditions. The reduction in forest cover due to agricultural intensification and the conversion from pasture to cropland (especially between 2000 and 2006) resulted in higher surface runoff volumes. These changes mostly affected the middle and downstream catchments of the main rivers which means that over the years, the soil water retaining capacity has decreased.
\end{abstract}

Keywords: Runoff volume, Land use/Land cover changes, Corine Land Cover, Țibleș

\section{INTRODUCTION}

Global climate change along with human population growth, movement and activities cause noteworthy changes in land surface properties. These changes can have major impacts on the water balance of any drainage system.

Any human activity that alters a natural catchment area, can lead to significant changes on its hydrological behaviour (Booth, 1991). A densely vegetated area as opposed to an artificial one, with higher levels of interception, has a significant resistance effect, thus lengthening the lag time, which is an integrated variable of the rainfall-runoff relationship and all the various watershed impact characteristics (Şarpe and Haidu, 2017). A proper knowledge concerning the surface runoff variability is of great importance for researchers involved in water management activities to reduce the impact of floods, such as runoff prediction (Sahour et al., 2014). Accordingly, monitoring and analyzing the catchment responses to LULC changes, ensures a sustainable management of water resources.

\footnotetext{
${ }^{1}$ Babeş-Bolyai University, Faculty of Geography, 5-7, Clinicilor Street, Cluj-Napoca, 400006, Cluj County, Romania, carinastrapazan@yahoo.ro ionel.haidu@geografie.ubbcluj.ro kfistvan@yahoo.com
} 
Numerous investigations of land use change effects on water balance have been conducted around the world, not only in tropical or subtropical (Mahmoud and Alazba, 2015; Yin et al., 2017; Shi et al., 2007; Karamage et al., 2017), but also in temperate regions (Ashagrie et al., 2006, Costache and Fontanine, 2013)

The SCS-CN is an efficient and widely used method for runoff estimation (Strapazan and Petrut, 2017) relying on the $\mathrm{CN}$ index which accounts for most of the watershed features such as AMC, land use/cover, soil types and texture (Gyori et al., 2016; Prakash and Sreedevi, 2017), with strong impacts on the mechanism of runoff generation .

In order to investigate the temporal and spatial LULC change patterns and their effects on runoff volume in various hilly and mountainous watersheds, the CLC databases along with the SCS-CN method were applied with regard to a frontal event with substantial amounts of precipitation. These changes were assessed over the entire study period (from 2000 to 2012) to observe their long-term characteristics and by comparing their short-term patterns (for the first 7-year period and the second one).

The sensitivity analysis of runoff to land use changes was carried out considering both total and spatially distributed runoff volumes for each grid cell, catchment and land use category.

Three adjacent watersheds located in the Țibleș and Rodnei Mountains were purposively selected for this study, due to the fact that their flood-prone areas (e.g.,the downstream section of Țibleș from Zagra to Mocod, the section of Telciu between Telciu and Telcișor, Romuli, Dealul Ștefăniței and Coșbuc villages) are among the most important ones in the Someș-Tisa hydrographic area, according to the historical reports from 1991 to 2013 (PPPDEI, 2014).

\section{STUDY AREA}

Located within the county of Bistrița-Năsăud, the study area encompasses the Țibleș, Runc and Sălăuța watersheds and is composed of mountainous and hilly terrain. All three are right bank tributaries of the Someșul Mare river which meets the Someșul Mic river upstream of Dej city, to form the Someș river.

The Tibleș Mountains are the home of the headwaters of Tibleș and Sălăuța rivers while the Runc river originates from the Năsăud Hills, located in the southern side of the mountains. The Sălăuța river collects its waters not only from the eastern and southeastern sides of the Tribleș Mountains, but also from the western slopes of the Rodna Mountains, draining the Năsăud Hills towards the south. The Țibleș river also drains the Năsăud Hills, but collects its waters from the southern slopes of the Țibleș Mountains. The catchment areas range greatly in size from $49 \mathrm{~km}^{2}$ (Runc) to $99 \mathrm{~km}^{2}$ (Țibleș) and $414 \mathrm{~km}^{2}$ (Sălăuța).

Suplai, Zagra, Runcu Salvei, Romuli, Telciu and Coșbuc are among the main settlements in the area (Fig. 1). The watersheds are monitored on a daily basis by the Bistrița-Năsăud Water Management System and the National Administration "Romanian Waters", Someș-Tisa Water Directorate, except for the Runc watershed. 


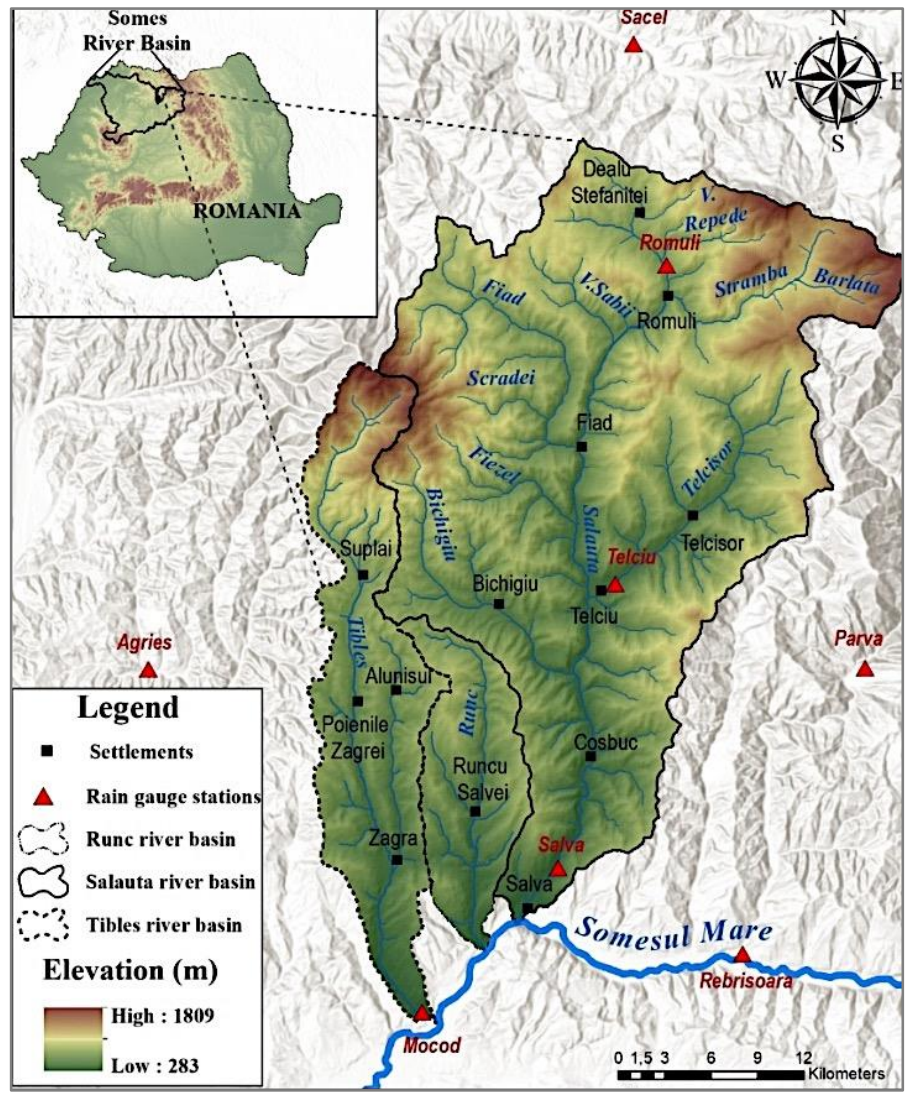

Fig. 1. Location map of the study area

\section{DATA AND METHODS}

In order to quantify the LULC changes on surface runoff, a frontal rainfall event that occurred on the $5^{\text {th }}$ of September 2015 was chosen. The data was collected from 6 hydrometric stations (Săcel, Romuli, Telciu, Salva, Mocod, Rebrișoara) and 2 rain gauge stations (Parva and Agrieș). located in the proximity of the study area. The event was chosen for two main reasons. First of all, the analysis of the raingauge observation data recorded since 2006 until present day, revealed that the above mentioned event was the most relevant for the study. High amounts of rainfall were recorded by all the selected stations (e.g., Parva-37,8 mm, Rebrișoara-45,3 mm , Salva-34 mm). Furthermore, the Mocod station recorded the greatest precipitation amount $(50 \mathrm{~mm})$ in the studied period. Secondly, given the large size of the chosen area $\left(562 \mathrm{~km}^{2}\right)$ and the primary objective of this study, a widespread frontal event with large rainfall amounts and considerable spatial homogeneity was needed.

The digital elevation model for Europe (EU-DEM) with a resolution of $25 \mathrm{~m}$ from the GMES RDA project (a realisation of the Copernicus programme, managed by the 
European Commission, DG Enterprise and Industry) from the website of the European Environment Agency (EU-DEM Metadata) was used to subtract information on relief. In order to automatically delineate the watersheds a model based on the elevation data and ArcHydro functions was used (Strapazan and Petrut, 2017).

For the information on spatial distribution of LULC and soils, the CLC 2000, 2006 and 2012 raster datasets (available from the European Environment Agency) along with the soil map (provided by the National Research and Development Institute for Soil Science, Agrochemistry and Environment) were used. The CLC 2000 data validation was assessed based on a reinterpretation of IMAGE2000 and Eurostat LUCAS data (Maucha and Büttner, 2006). The CLC 2000 and 2006 layers were revised (V18_5) and an independent validation of CLC 2012 was performed in 2016 (EEA, 2016). The process of estimating the $\mathrm{CN}$ was based on the one described in the scientific literature (Haidu et al., 2017, Crăciun et. Al, 2007, Strapazan and Petrut, 2017) (Fig. 2).

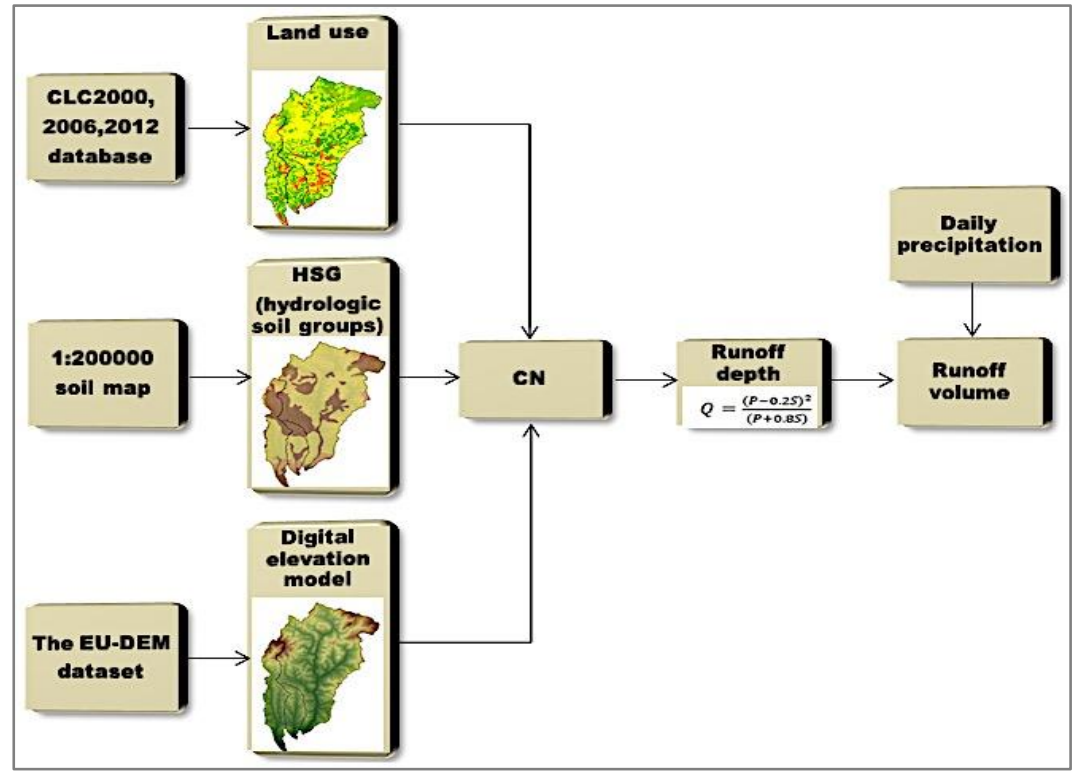

Fig. 2. Flow chart showing the main steps for runoff volume estimation

The $\mathrm{CN}$ index was adjusted according to different antecedent moisture conditions. In this case, the equation for initial abstractions takes into account the $\beta$ coefficient that represents the water holding capacity over time for different vegetation types and thus, considering the process dynamics (Crăciun et al., 2009, Crăciun, 2011).

\section{RESULTS}

The CORINE dataset has 3 hierarchical levels for the land cover type classification, ranging from micro to macro-scale. For a preliminary analysis of the terrain, in order to observe the spatial distribution of land use characteristics, the third and the second 
levels were used (Fig. 3). According to this evaluation, the Țibleș watershed has the highest land use diversity with large areas occupied by forests, pastures, agricultural heterogenous crops, scrub and herbaceous vegetation and smaller urban, arable (under rainfed farming) and fruit production areas (permanent crops). Except for the permanent crops and arable land (non-irrigated), all three watersheds share the same land use structure. Accordingly, this is a homogenous area of agricultural activities.

As regards the land use structure between 2000 and 2012, the watersheds share the same pattern of land use change. There was a loss in forest cover and pastures due to agricultural expansion. The Runc watershed exhibited the highest changes. In 2000 forests covered about $50 \%$ of its total area as opposed to $33 \%$ in 2012 and the agricultural areas have increased by over $13,7 \%$. The Runc watershed experienced higher changes in forest cover for the last 7-year period compared to the other ones.

Overall, the highest changes occurred between 2000 and 2006 with the conversion of forest land to agricultural use. Thus, the heterogenous agricultural areas increased by $8,2 \%, 6,8 \%$ and $4,4 \%$ of the total catchment areas of Runc, Țibleș and Sălăuța, respectively.
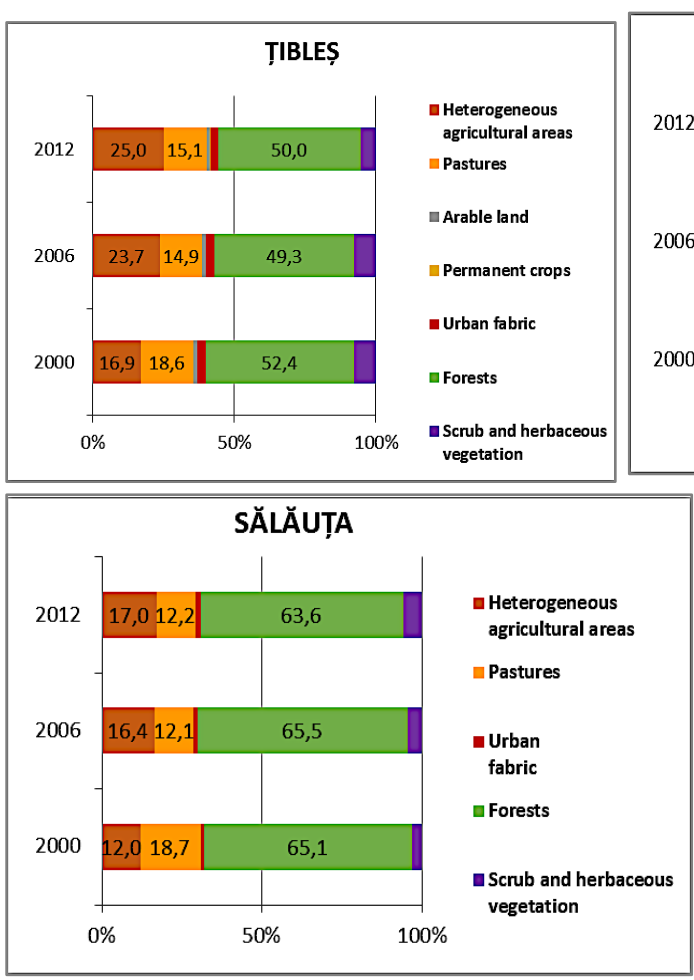

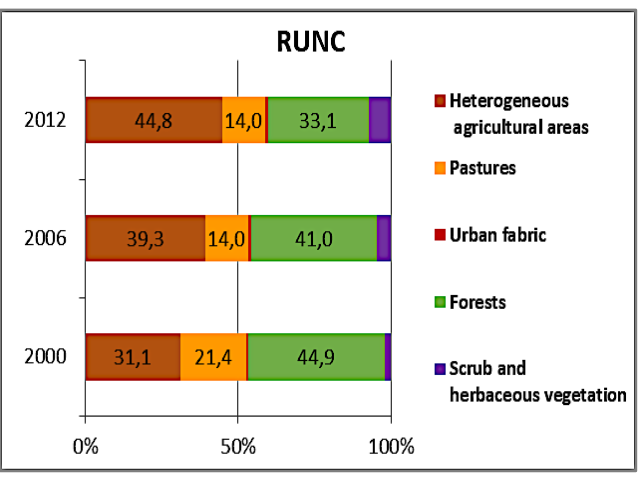

Fig. 3. The dynamics of land use/land cover change in all three river basins (percentage of total area)

Therefore, considering the entire study area, the base year of 2000 and the micro-scale classification of land uses, the complex cultivation, orchard, natural grassland, moor and heathland areas experienced the most notable changes that took place during the first seven years of the studied period. The natural grassland areas had nearly doubled in size, leading to the disappearance of moors and 
heathlands, and the complex cultivation areas have increased by over $50 \%$. The orchards had the highest increase in area, although in 2000 they occupied just 1 $\mathrm{km}^{2}$ of the total Țibleș river catchment area (Fig. 4).

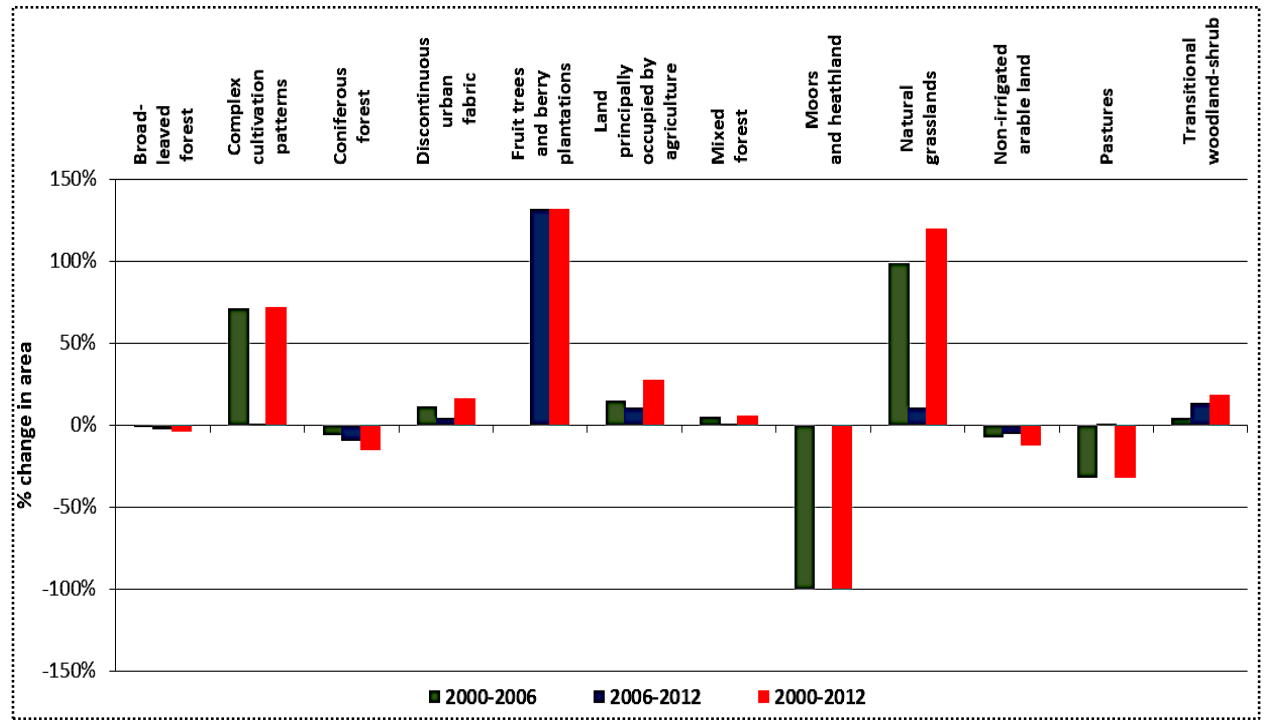

Fig. 4. Graph showing the percentage change in area of different land use/land cover types of the entire study territory

As mentioned above, the SCS-CN method was used for surface runoff simulation, the other key factors being considered constant, in order to accurately evaluate the land use-runoff relationship. The method was implemented in a GIS environment and the spatial statistics and analysis functions were used to compute the values.

Considering the maximum runoff volume per cell (pixel), the results revealed no significant difference between the time periods under the same AMC scenario. The explanation for this phenomena lies in the presence of the built-up areas and the main rivers flowing through them with no or low levels of infiltration. The minor differences are only present in the Sălăuța and Runc river basins reflecting a slight expansion of the urban fabric towards areas with higher precipitation amounts for this event.

The average runoff values (per pixel) tend to increase together with agricultural areas expansion, except for the Sălăuța and Țibleș river basins, in which case this increase is observed only between 2000 and 2006, (given the fact that the major changes occurred during this time period). As a consequence of experiencing high changes regarding the land use, the Runc watershed shows upward trends in runoff volumes during the entire period.

With the exception of the Sălăuța watershed, there was an increase in the minimum runoff values (Table 1 ).

Based on the spatial distribution of the runoff volumes, regardless of the antecedent moisture conditions, the largest changes can be observed in the middle 
and downstream catchments of the main rivers where agricultural activities are the most intense and the few forested areas existent here, actually shrunk over time.

Table 1. Estimated runoff volumes at cell (pixel) level

\begin{tabular}{|c|c|c|c|c|c|c|c|c|c|c|}
\hline \multirow{3}{*}{ Watersheds } & \multirow{3}{*}{$\begin{array}{l}\text { AMC } \\
\text { classes }\end{array}$} & \multicolumn{9}{|c|}{ Runoff volume ( $\mathrm{m}^{3} /$ cell) } \\
\hline & & \multicolumn{3}{|c|}{2000} & \multicolumn{3}{|c|}{2006} & \multicolumn{3}{|c|}{2012} \\
\hline & & Min. & Mean & Max. & Min. & Mean & Max. & Min. & Mean & Max. \\
\hline \multirow{3}{*}{ TIBLES } & AMC1 & 0,0 & 1,5 & 13,8 & 0,0 & 1,7 & 13,8 & 0,0 & 1,7 & 13,8 \\
\hline & AMC2 & 0,0 & 4,6 & 18,8 & 0,0 & 4,9 & 18,8 & 0,1 & 4,9 & 18,8 \\
\hline & AMC3 & 2,1 & 8,7 & 23,2 & 2,1 & 9,0 & 23,2 & 2,6 & 9,0 & 23,1 \\
\hline \multirow{3}{*}{ RUNC } & AMC1 & 0,0 & 1,8 & 8,5 & 0,0 & 1,9 & 8,5 & 0,0 & 2,0 & 8,6 \\
\hline & AMC2 & 0,0 & 5,3 & 14,7 & 0,0 & 5,4 & 14,7 & 1,0 & 5,5 & 14,9 \\
\hline & AMC3 & 2,0 & 9,6 & 18,9 & 2,0 & 9,7 & 18,9 & 4,0 & 9,8 & 19,1 \\
\hline \multirow{3}{*}{ SALAUTA } & AMC1 & 0,0 & 0,8 & 11,2 & 0,0 & 0,9 & 11,2 & 0,0 & 0,9 & 12,0 \\
\hline & AMC2 & 0,0 & 3,3 & 15,5 & 0,0 & 3,4 & 15,5 & 0,0 & 3,4 & 16,6 \\
\hline & AMC3 & 0,1 & 6,8 & 17,9 & 0,1 & 6,9 & 17,9 & 0,1 & 6,9 & 19,0 \\
\hline
\end{tabular}

Furthermore, the spatial distribution of runoff volumes reveals lower values in the headwater areas and higher values in the downstream catchment areas where notable changes affected the plant cover (Fig. 5, Fig. 6, Fig. 7).

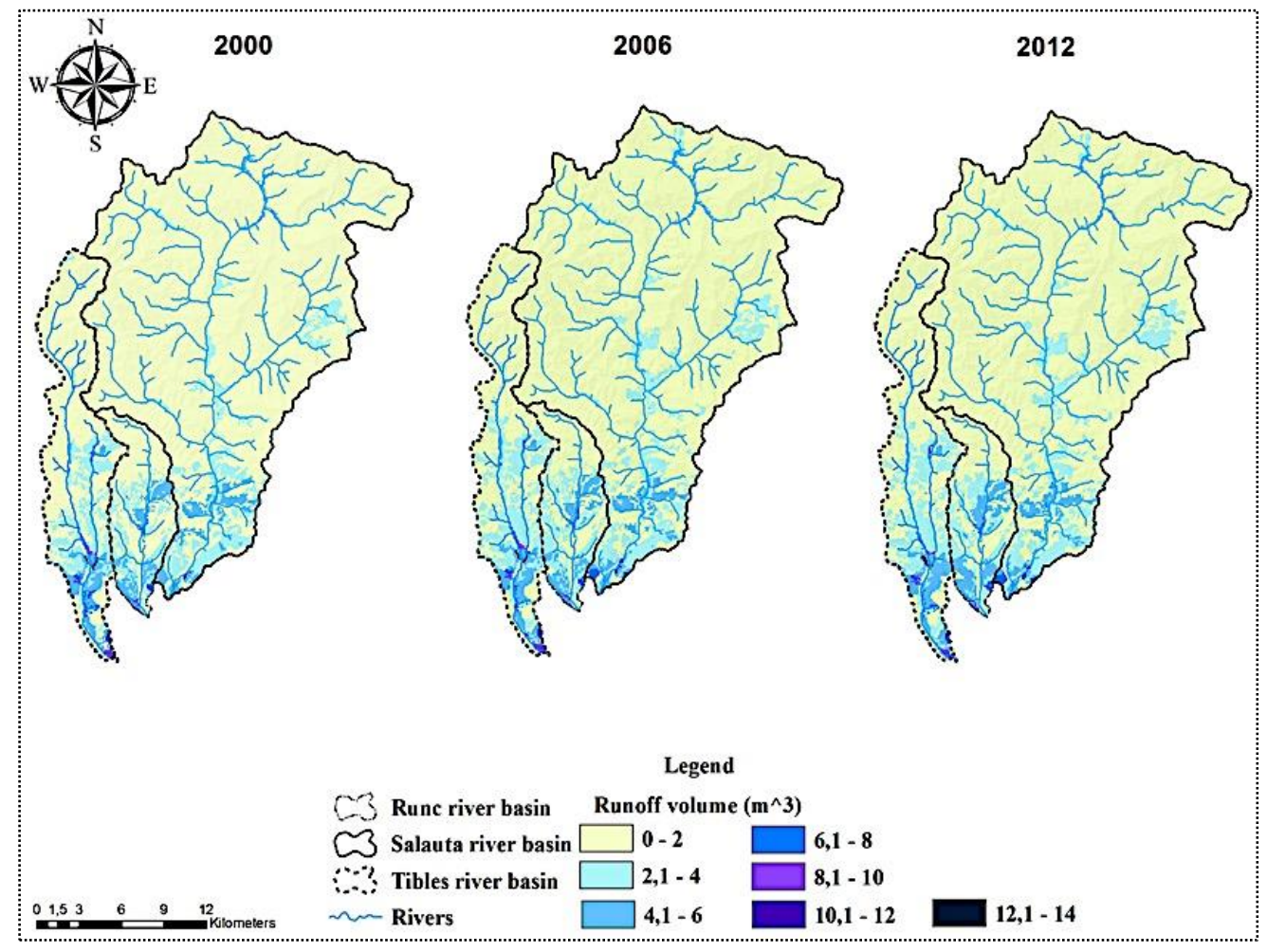

Fig. 5. Spatiotemporal distribution of runoff volumes under dry soil moisture conditions 


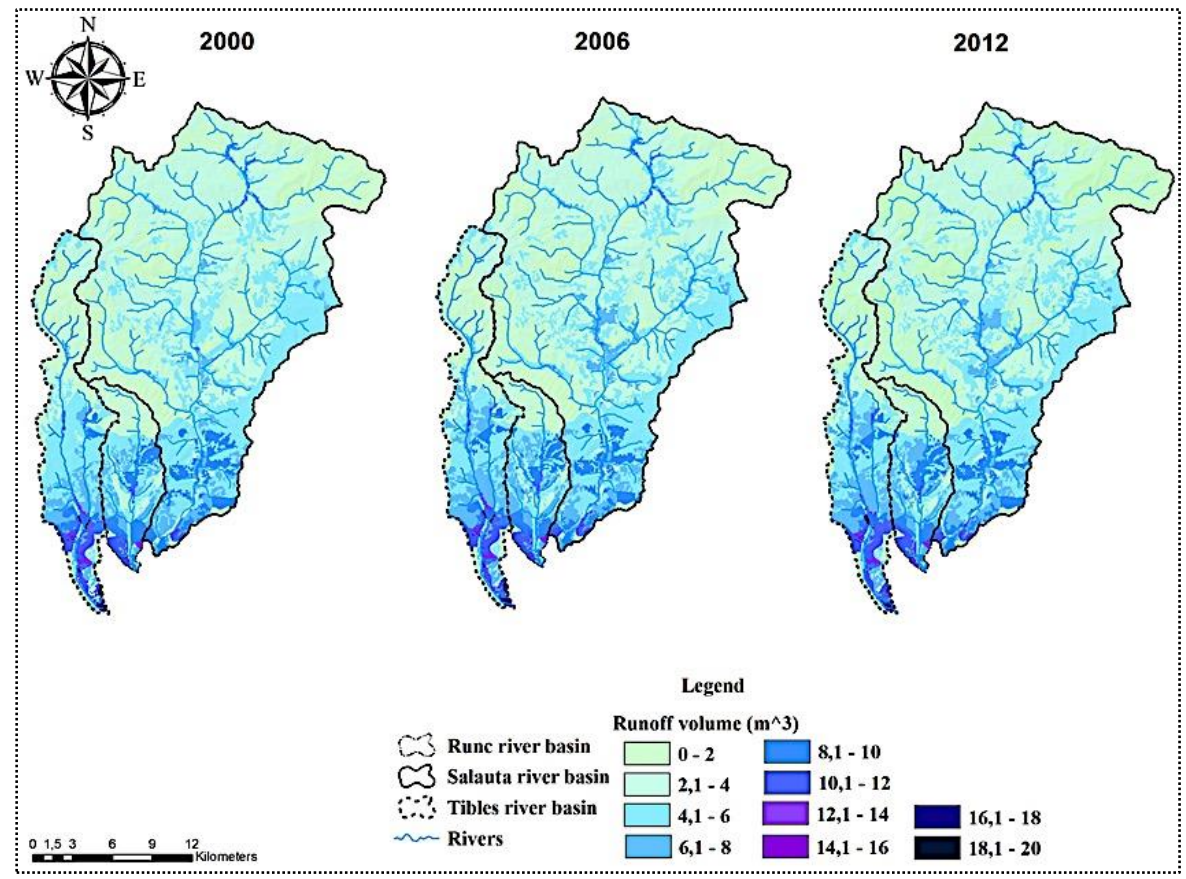

Fig. 6. Spatiotemporal distribution of runoff volumes under normal soil moisture conditions

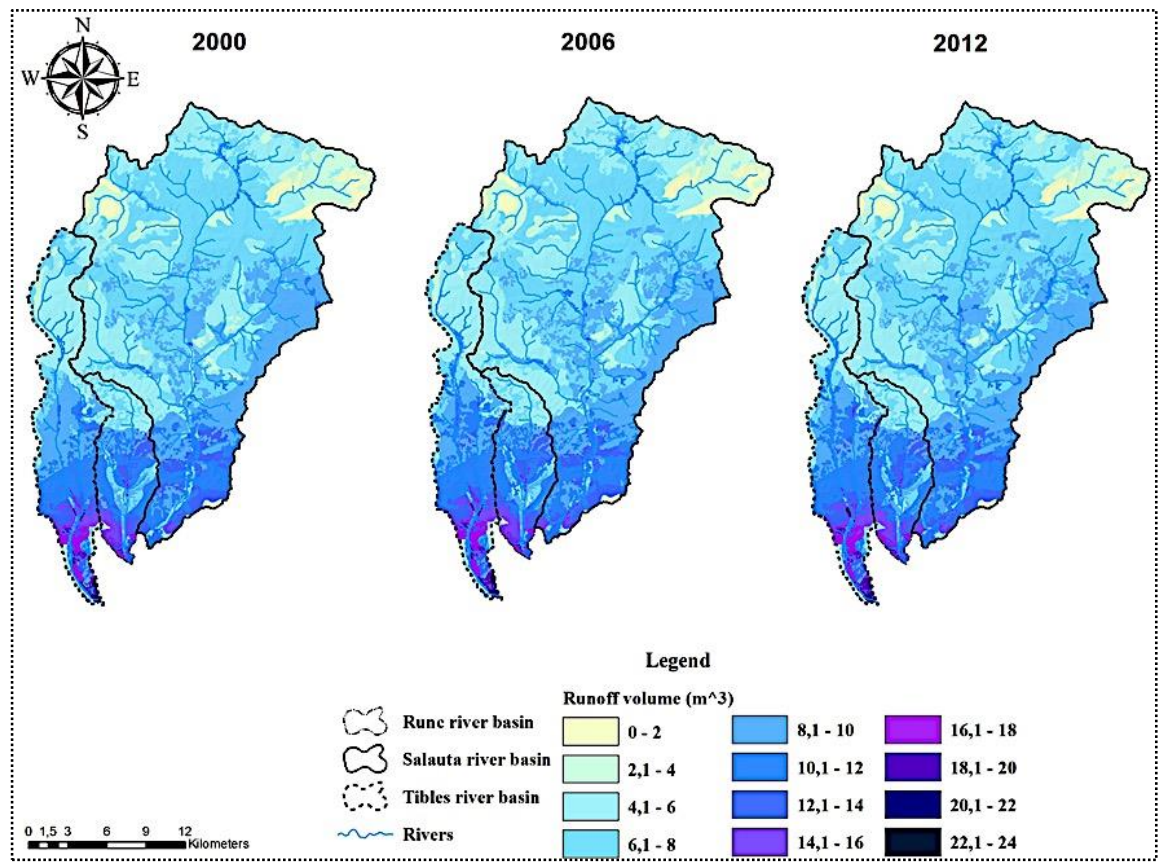




\section{Fig. 7. Spatiotemporal distribution of runoff volumes under wet soil moisture conditions}

According to the chosen rainfall event scenario, notable differences in each catchment area's total runoff volume have been observed over time (Table 2).

Table 2. The total estimated runoff volume

\begin{tabular}{|c|c|c|c|c|}
\hline \multirow{3}{*}{ Watersheds } & \multirow{2}{*}{$\begin{array}{c}\text { AMC } \\
\text { classes }\end{array}$} & \multicolumn{3}{|c|}{ Total runoff volume $\left(\mathbf{m}^{\mathbf{3}}\right)$} \\
\cline { 3 - 5 } & & $\mathbf{2 0 0 0}$ & $\mathbf{2 0 0 6}$ & $\mathbf{2 0 1 2}$ \\
\cline { 3 - 5 } & Sum & Sum & Sum \\
\hline \multirow{3}{*}{ TIBLES } & AMC1 & 240440 & 268311 & 270517 \\
\cline { 2 - 5 } & AMC2 & 732517 & 770718 & 774670 \\
\cline { 2 - 5 } & AMC3 & 1381816 & 1416492 & 1421849 \\
\hline \multirow{3}{*}{ RUNC } & AMC1 & 141369 & 150738 & 157419 \\
\cline { 2 - 5 } & $A M C 2$ & 412915 & 422658 & 427118 \\
\cline { 2 - 5 } & AMC3 & 750266 & 759371 & 762513 \\
\hline \multirow{3}{*}{ SALAUTA } & AMC1 & 545683 & 577335 & 585489 \\
\cline { 2 - 5 } & $A M C 2$ & 2172470 & 2218413 & 2233001 \\
\cline { 2 - 5 } & AMC3 & 4510732 & 4560759 & 4577983 \\
\hline
\end{tabular}

By analyzing these changes as a percentage of the base values (from the begining of each study time period), the same pattern could be observed for all of the catchment areas, with greater changes between 2000 and 2006, strongly linked to the changes in vegetation (Fig. 8).

Although the same pattern of land use changes applies to all of the antecedent moisture conditions, according to the dry soil (AMC1) scenario, as opposed to the normal (AMC2) and wet ones (AMC3), higher changes in the total runoff volume between different years were observed. From 2000 to 2006 the total runoff volume at the outlet of the Tibleș catchment area has increased by $11,6 \%$. Within the same time frame the total runoff volumes computed for the Runc and Sălăuța watersheds, increased by $6,6 \%$ and $5,8 \%$, respectively.

The minimal percentage changes of runoff volume were observed for AMC3 scenario. The land use change effect on surface runoff volumes is very small under wet soil conditions. When high rainfall events occur, the infiltration rate decreases as the soil becomes oversaturated with water and the infiltration coefficient decreases as the runoff one increases. Under normal AMC, for this rainfall event, the runoff volumes computed for the Țibleș watershed increased by 5,2\% in 2006 and by 5,8\% in 2012. Considering the totals computed for the Runc watershed, increases of 2,4\% and 3,4\% are observed in 2006 and 2012, respectively.

With regards to the total study area and the contributions of each land use type to the total runoff volume, the main source of runoff is the vast forested area. Nevertheless, as a wide range of agricultural practices intensify, the forest's influence on the runoff coefficients and velocities decreases (Fig. 9).

If the agricultural runoff volume in the year 2000 represented $25 \%$ of the total volume of runoff under normal moisture conditions, with regards to such a rainfall event, by the year 2012, this value would have reached $34,5 \%$. Built-up areas that 
usually present the highest runoff potential, have in this case a limited influence, as they don't have a wide territorial spread.
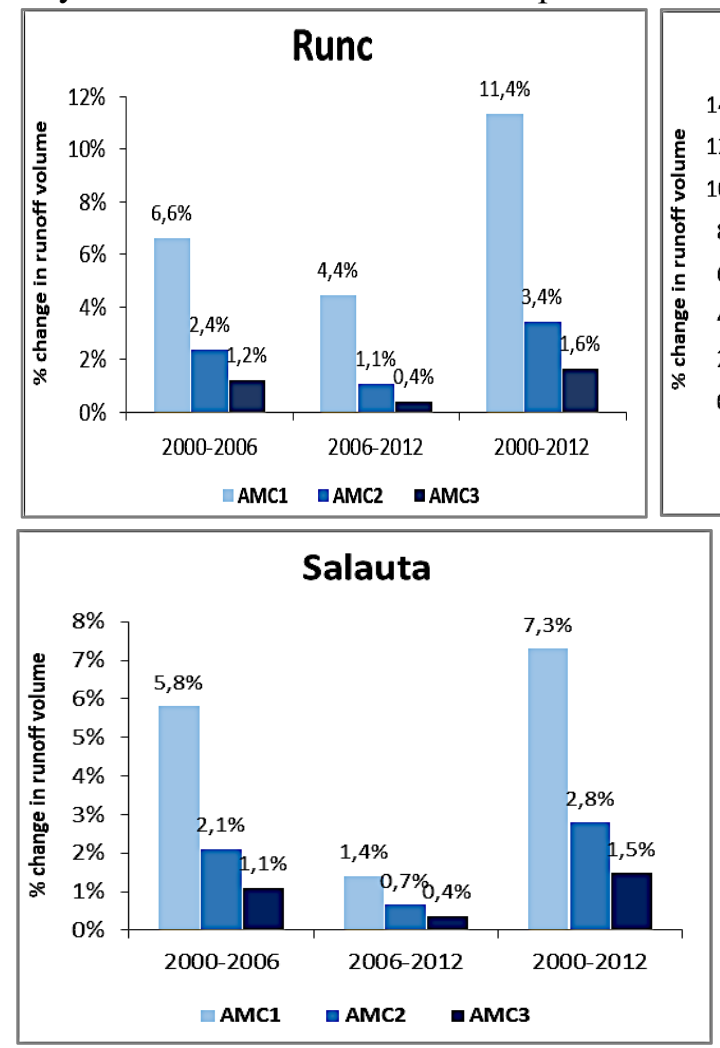

\section{Tibles}

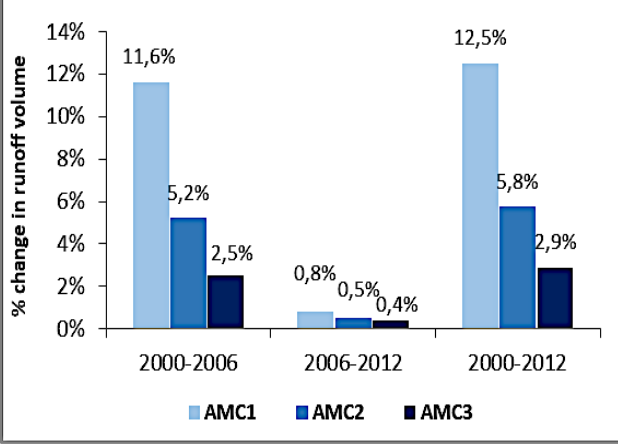

Fig. 8. The relative changes in surface runoff volume under different soil moisture conditions

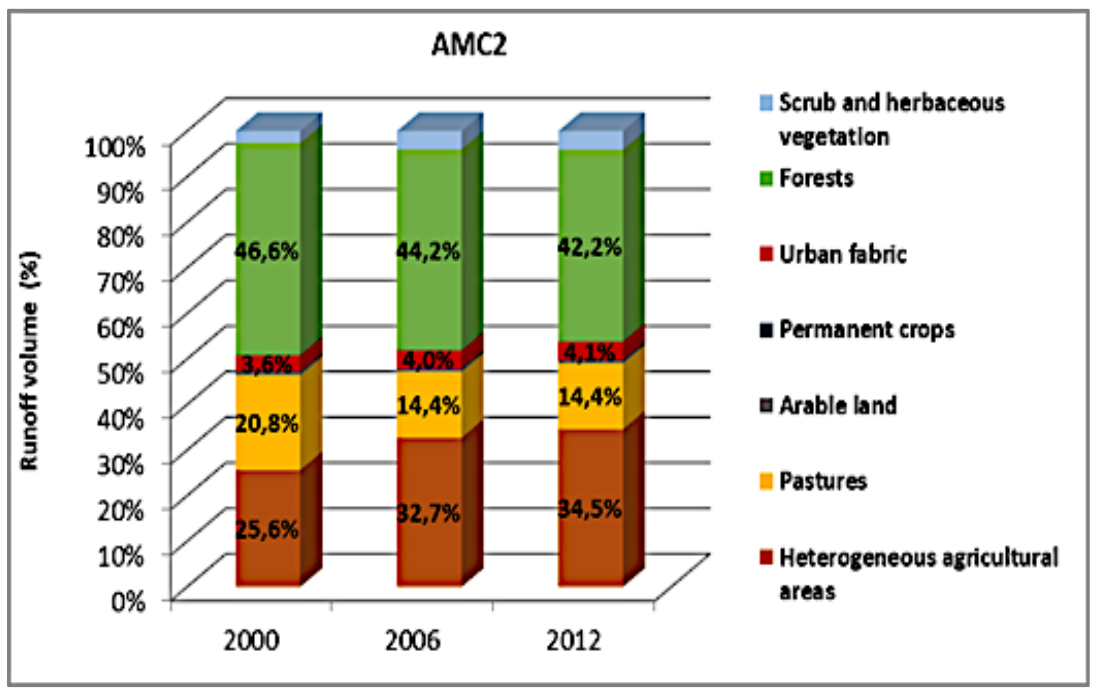




\section{Fig. 9. The contribution of each land use type to the total runoff volume under normal soil moisture conditions}

\section{CONCLUSIONS}

This research was based on the most relevant frontal rainfall event from the past twelve years which was used as a scenario for runoff volume estimation, according to historical land use changes, in order to determine their effects on the water balance The analysis revealed that the whole area can be very sensitive to agricultural exploitation and crop diversity practices with higher runoff potential.

. The Runc watershed was subjected to the biggest changes, with agricultural areas increasing by over $13,7 \%$ in 2012 compared to the base year of 2000 . The biggest rate of conversion from forested areas and pastures to agricultural areas was observed between 2000 and 2006 with increases of 8,2\% 6,8\% and 4,4\% of the total catchment areas of Runc, Țibleș and Sălăuța, respectively. According to the antecedent moisture scenarios, greater changes were observed for the AMC1 conditions between 2000 and 2006 with runoff volumes increases of 11,6\%, 6,6\% and 5,8\% computed for Țibleș, Runc and Sălăuța, respectively.

However, between 2006 and 2012, the changes were not that significant as opposed to the above mentioned period. If this tendency is to continue, it might lead towards a stagnation of agricultural exploitation and a reduced runoff potential. Regardless, the Runc watershed area seems to be the exception in this case as the agricultural exploitation was only slightly smaller during the second 7year period, compared to the first one. Considering all these and giving the fact that it is an ungauged river basin, there might be a need to increase awareness of its hydrological processes.

\section{REFERENCES}

1. Ashagrie A. G., De Laat P. J., De Wit M. J., Tu M., Uhlenbrook S. (2006), Detecting the influence of land use changes on discharges and floods in the Meuse River Basinthe predictive power of a ninety-year rainfall-runoff relation? Hydrology and Earth System Sciences, 10(5), 691-701. DOI: 10.5194/hessd-3-529-2006.

2. Booth D.B. (1991), Urbanization and the Natural Drainage System - Impacts, Solutions, and Prognoses. Northwest Environmental Journal, 7(1), 93-118.

3. Costache R., Fontanine I. (2013), Land use changes in the subcarpathian area between Buzău and Slănic rivers, during 1990- 2006 and their consequences on surface runoff. Riscuri și Catastrofe, 13(2) 171-182.

4. Crăciun A. I. (2011), Estimarea indirectă, cu ajutorul GIS, a umezelii solului $\hat{\imath}$ scopul modelării viiturilor pluviale. Aplicații în Munții Apuseni. PhD Thesis, "Babeș-Bolyai University", Cluj-Napoca, Romania. (in Romanian).

5. Crăciun A. I., Haidu I., Magyari-Saska Zs., Imbroane A. I. (2009), Estimation of runoff coefficient according to soil moisture using GIS tehchniques. Geographia Technica, 9(2), 1-10.

6. Crăciun, A.I., Haidu, I. \& Bilaşco, Şt. (2007), The SCS-CN model assisted by G.I.S.alternative estimation of the hydric runoff in real time. Geographia Technica, 2(1), 1-7. 
7. Gyori M-M., Haidu I., Humbert J. (2016), Deriving the floodplain in rural areas for high exceedance Probability Having Limited Data Source. Environmental Engineering and Management Journal, 15(8), 1879-1887.

8. Haidu I., Batelaan O., Crăciun A.I., Domnița M. (2017), GIS module for the estimation of the hillslope torrential peak flow. Environmental Engineering and Management Journal, 16(5), 1137-1144. DOI: 10.30638/eemj.2017.118.

9. Karamage, F., Zhang C., Fang X., Liu T., Ndayisaba F., Nahayo L., Kayiranga A., Nsengiyumva J.B. Modeling Rainfall-Runoff Response to Land Use and Land Cover Change in Rwanda (1990-2016). Water, 9(3), 147. DOI:10.3390/w9020147.

10. Mahmoud S.H., Alazba A.A. (2015), Hydrological Response to Land Cover Changes and Human Activities in Arid Regions Using a Geographic Information System and Remote Sensing. PLOS ONE, 10(4), 1-19. DOI:10.1371/journal.pone.0125805.

11. Maucha C., Büttner G. (2006), Validation of the European CORINE Land Cover 2000 database. In A. Marcal (Ed.), Global developments in environmental Earth observation from space. Proceedings of the 25th EARSeL Symposium. Porto, Portugal, 6-9 June 2005, Rotterdam:Millpress, 449-457.

12. Prakash, C.R., Sreedevi, B. (2017), Land-Use Land-Cover Change and Its Impact on Surface Runoff using Remote Sensing and GIS. International Journal of Advanced Remote Sensing and GIS, 6(1), 2103-2113. DOI: 10.23953/cloud.ijarsg.237.

13. Sahour H., Mokhtari A., Tehrani E. N. (2014), Effects of Land Use/Land Cover changes on surface runoff (A case study in Siahroud Watershed, Iran). Elixir International Journal, 74, 26867-26870.

14. Shi P-J., Yuan, Y., Zheng J., Wang, J-A, Ge Y., Qiu, G-Y (2007), The effect of land use/cover change on surface runoff in Shenzhen region, China. Catena 69, 31-35. DOI: 10.1016/j.catena.2006.04.015.

15. Strapazan C., Petruț M. (2017), Application of Arc Hydro and HEC-HMS model techniques for runoff simulation in the headwater areas of Covasna Watershed (Romania). Geographia Technica, 12(1), 95-107. DOI: 10.21163/GT_2017.121.10.

16. Șarpe C.A., Haidu I. (2017), Temporal sampling conditions in numerical integration of hydrological systems time series. Geographia Technica, 12(1), 82-94. DOI: 10.21163/GT_2017.121.09.

17. Yin, J., He F., Xong Y.J., Qiu G.,Y (2017), Effects of land use/land cover and climate changes on surface runoff in a semi-humid and semi-arid transition zone in northwest China. Hydrology and Earth System Sciences, 21(1), 183-196. DOI:10.5194/hess-21-183-2017.

18. ***EEA (European Environment Agency) (2016), Corine Land Cover 2012 (vector) - version 18, Sep. 2016, https://sdi.eea.europa.eu/catalogue/srv/api/ records/8e7b1303-974d-49ac-959d-a2527a844561. Accessed on 06.12.2018.

19. ***EU-DEM Metadata, https://www.eea.europa.eu/data-and-maps/data/eudem\#tab-metadata. Accessed on 04.12.2018.

20. ***PPPDEI (2014), Planul pentru prevenirea, protecția și diminuarea efectelor inundațiilor în bazinul hidrografic Someș Tisa, S.C. AQUAPROIECT S.A. (in Romanian). 